\title{
Tobacco Farming Mapping To Determine The Number Of Plants Using Contour Detection Method
}

\author{
Diana Rahmawati*, Riza Alfita, Miftachul Ulum and Dedek Murdianto \\ Department of Electrical Engineering, University of Trunojoyo Madura, 69162, Indonesia
}

\begin{abstract}
Indonesia's climate has suitable for tobacco growth. tobacco plants can live in drylands. Tobacco is planted optimum with a size of $100 \mathrm{~cm} \times 70 \mathrm{~cm}$. The right size is used to count the amount of tobacco that will be planted according to the area of the land. Technology developed to help the farmer to monitor their crops and yields, by using image processing. Farmers can count easily without having to go to the field to calculate manually. In our research, image processing is used combined with knowledge base data. Images taken using drones, then be processed using image processing using the contour detection method to count the number of a tobacco plant. The results of 80 times system testing, which is using 4 parameters, 20 samples for each parameter. The success rate of the first test was $86.597 \%$ with a $13.402 \%$ error rate. The second test's success rate is $87.63 \%$ with a $12.306 \%$ error rate. of the third test obtained an $87.033 \%$ success rate and an error rate of $12.966 \%$. The fourth test results from an $85.431 \%$ success rate and $14.56 \%$ error rate.
\end{abstract}

Keywords: Contour Detection Method; Drone; Tobacco plant; Mapping; Image Processing

\section{Introduction}

As a tropical plant, however, the area of tobacco cultivation is quite wide, they can grow in hot climates such as Indonesia or cold climates. [1]. Tobacco's plant does not require much water, so they can grow in the dry season. Tobacco is planted optimum with a size of $100 \mathrm{~cm} \times 70 \mathrm{~cm}$. [1] The right size is used to count the amount of tobacco that will be planted according to the area of the land. By using drone technology, calculations can also be made automatically when tobacco is embedded. The image from the drone then is processed by the image processing method using the contour detection method. [2] In our research, image processing is used combined with knowledge base data. Images taken using drones, then be processed using image processing using the contour detection method to count the number of a tobacco plant. By image processing results number of plants planted by farmers on the land can be seen. The input from the system is an RGB image then be converted into an HSV image that becomes the system input[2], [3], [4]. After that, the image is processed using the contour detection method to determine the number of plants. The output of the system is the number of plants that have been detected. [5], [6]

\section{Method}

Precision agriculture in [4] and [5] was carried out by incorporating elements of information technology and mechanization in the plantation sector. Analysis of the relationship between visible and infrared drone sensors with oil palm plants can be done by shooting at oil palm blocks using drones with visible and infrared sensors. For shooting using a drone by creating a flight path using mission planner software with an aircraft height ranging from 300-350 meters above sea level. Furthermore, the image mosaic process is used, in the form of combining several photos so that they become a single unit. The merging of these photos is a rectification of drone photos, composites of original color 321 and infrared 432. To monitor oil palm health, this system uses two drone analyzes, namely visual analysis, and digital NDVI analysis.[4]

In [5] the results of the image or video are analyzed and processed using a $\mathrm{PC}$ with a computer vision algorithm in the counting process, utilizing computer vision techniques from palm tree data taken and reprocessed with edge detection techniques, so that the drone can indicate which trees are ordinary and which are. palm trees which are then combined with pattern recognition methods. The final process of this research is to put a marking on the drone in the form of a red circle and start counting the number and monitoring the palm oil. [5], [6]

\footnotetext{
* Corresponding author : diana.rahmawati@trunojoyo.ac.id
} 


\subsection{Tobacco}

Tobacco is one of the most popular plants in the world. Tobacco is a seasonal agricultural product that is not a food commodity, but a plantation commodity. This plant is consumed not for food but as raw material for cigarettes and cigars. Tobacco can also be chewed (Nginang) the term in Javanese. Tobacco is also useful as a pesticide and medicinal raw material because it is rich in secondary metabolites. Tobacco plants are strongly influenced by cultivation methods, planting locations, seasons/weather, and processing methods. The tobacco agroecosystem affects the quality of tobacco produced. In Indonesia, good tobacco is only produced in certain areas. [3]

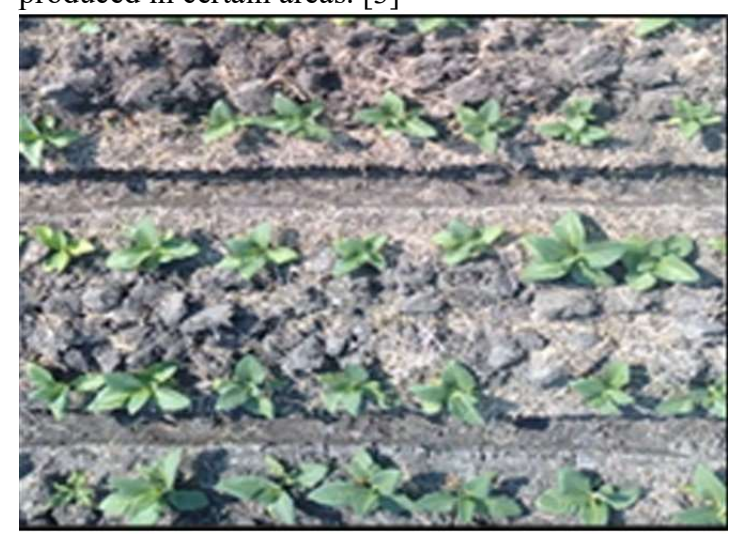

Fig. 1. Tobacco

\subsection{Pixel, Resolution, Intensity}

Pixel (Picture Elements) is the value of each matrix on the bitmap where the value of the pixel length will affect the color to be displayed. If a bitmap in a digital image displays 256 colors, the pixel value will be limited from 0 to 255 . And the quality of the bitmap will appear if it has the highest color from a bitmap that appears. It can be seen from the example in Figure 2 which gives an example of two bitmaps that can have different ways of handling the white to black transition. [4][9][7]

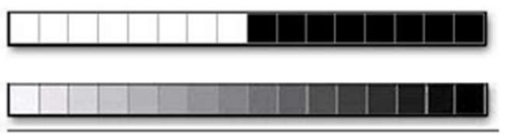

\section{Fig. 2. Bitmap Colour}

From the difference in Figure 2, it is explained that if the color of the bitmap above is less than the one below it, therefore from the two Figures 2, it can be seen that the difference in the accuracy of the value and color is very clear. [5][10][11]

\subsection{Morphology Operation}

Morphology is a method or method in digital image processing by utilizing the shape of an object as a reference for processing. The comparison process between the corresponding pixel in the input digital image with its neighboring pixels can produce the value of each pixel in the digital image. [6] The order of appearance of the pixels can affect the morphological operations, regardless of the numerical value of the pixels so that morphological techniques are often used in binary image processing operations and also grayscale images.[12][13]

\subsection{Opening Operation}

The opening operation is a combined operation between erosion and dilation processes. The first process carried out is the erosion process and then continued with the dilation process by utilizing the same structural elements. The opening operation has the aim of improving the image object and smoothing the object's surface and reducing some pixels in certain areas that are too narrow and small if filled with additional elements. So that the final process of all areas that have a smaller size than the structural elements, will be removed using erosion operations, and then for the smoothing process dilation operations are used. [7]

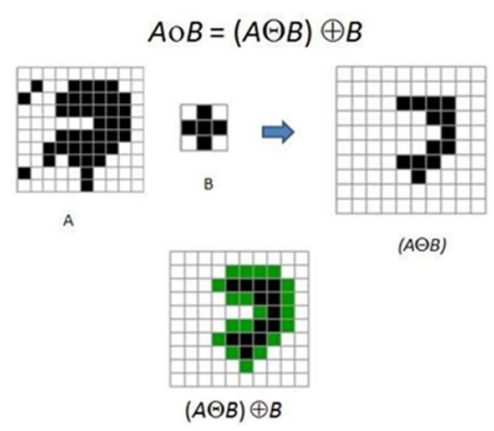

Fig. 3. Opening operation

\subsection{Closing Operation}

The closing operation aims to refine and smooth the contour. Also to remove small holes contained in the image. The closing operation has the following equation:

$$
\mathrm{A} \cdot \mathrm{B}=(\mathrm{A} \oplus \mathrm{B}) \Theta \mathrm{B}
$$

With:

$\mathrm{A}=$ image pixel $\mathrm{A}$

$B=$ image structured element $B$

Equation (1) is a closing morphology operation equation. [4]

$$
A \bullet B=(A \oplus B) \Theta B
$$

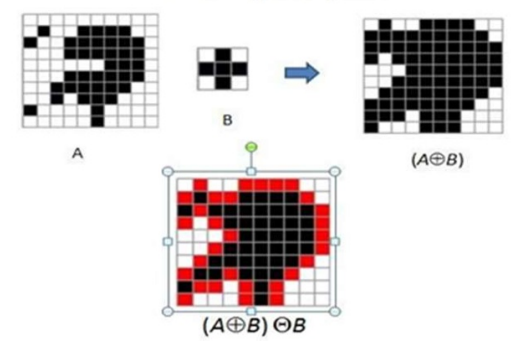

Fig. 4. Closing operation visual display 


\subsection{Phyton}

Python programming language is a high-level computer language that uses an interpreter as a translator medium, so all processes are carried out in the interpreter. The python programming language has many supporting libraries so that it can make python a programming language that has remained in demand from the past until now. Python provides strong support for integration with other programming languages and tools. Python comes with extensible standard libraries that can be learned in just a few days. A multipurpose interpretive programming language with a design philosophy that focuses on code readability. Python is claimed to be a language that combines capabilities, capabilities, with a very clear code syntax, and is equipped with a large and comprehensive standard library functionality. [8]

\section{Result and Discussion}

The implementation of this system discusses the testing of the whole series of the system which aims to test the system. The test results obtained will be analyzed with digital images. The tobacco plant counting system has the following display:

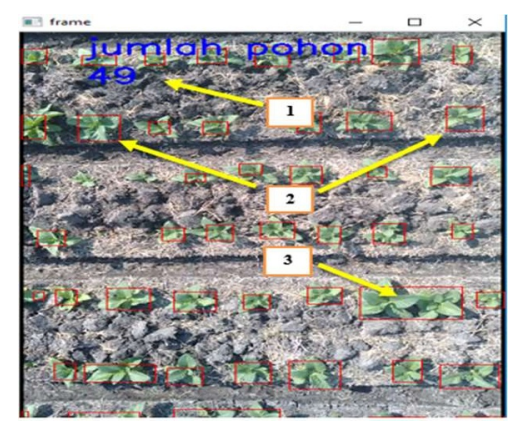

(1) shows the total number of detected plants

(2) shows the detected parts

(3) shows the detected object

Fig. 5. System's display

Hardware design using HP (mobile) and PC (personal computer) cameras. The camera will be connected to the PC by utilizing the Wireless connection. The camera is an input medium from the system that will be processed via a PC to produce output in the form of the number of plants detected by the system. The block diagram can be seen in Figure 9 below:

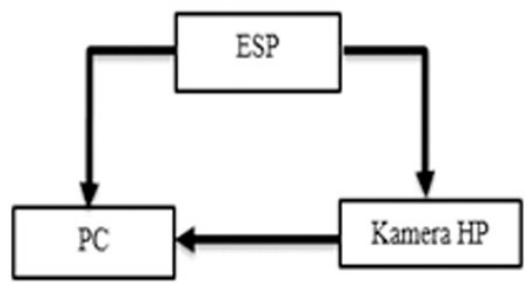

Fig. 6. Block Diagram

\subsection{Hardware Design}

Hardware or hardware is a hardware component that looks physical and is the driver of a command that has been programmed in the software. In designing intelligent equipment, we need hardware (hardware) that can process data, calculate, remember and make choices. In the automatic plant detection system, a laptop is needed, which functions like monitoring, as well as a programming system. Cell phone camera as an image capture tool. The ESP 8266-01 module serves as a wireless source, connecting the camera and laptop so that the detection process can run live/streaming. Syma X8Pro drone as a medium for taking aerial images.[14][15]

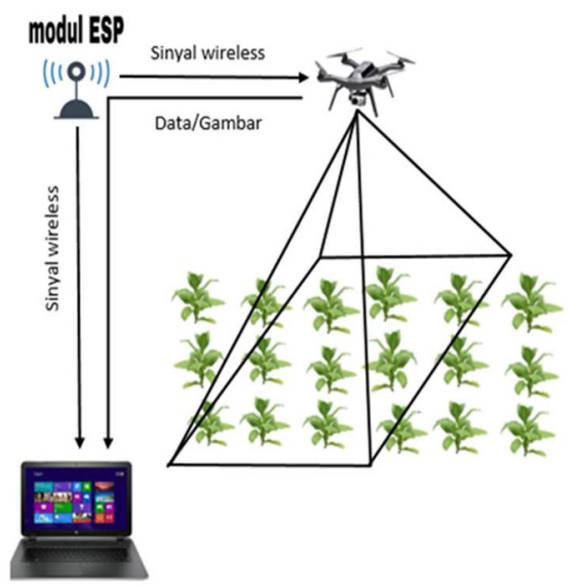

Fig. 7. Hardware Design

\subsection{Software Design}

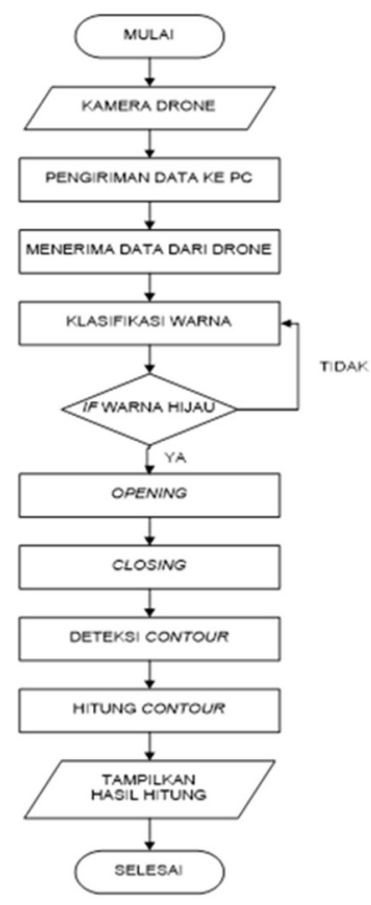

Fig. 8. Software Design 
The flow of Figure 11 begins with doing the first step to start by opening an application or software. The second stage is the process of taking pictures using a cellphone camera mounted on a drone. Taking pictures is done with a predetermined distance, starting from the near point to the farthest point. The process of taking pictures is done directly, so it is connected to a PC.

The input data (image) is in the form of RGB data which will be processed later. Then the third stage is the process of sending data directly (streaming) using a wireless connection as a liaison between the drone camera (HP camera) and PC (Personal Computer). The fourth stage is the process of receiving data sent by the drone (HP camera) to the PC, the data sent is in the form of RGB data which will then be converted to HSV. The sending process is connected using a wireless connection that is connected with the same IP. So that pictures taken using a cellphone camera can be displayed on the PC screen. The fifth stage is the color classification process by utilizing color detection to separate the object color (green) from the background color (black). This is so that objects can be detected correctly. So that the detection results allow having a slightly reduced error.

The sixth stage, namely the closing method, aims to increase or enlarge the pixels of the object shape, according to the structuring elements. In addition, to smooth the boundaries of objects without changing the object area significantly. The seventh stage, namely the opening method, aims to reduce or minimize pixels from the shape of the object, according to the structuring elements. Generally used to smooth the boundaries of large objects without changing the object area significantly, the eighth stage is used to detect objects (tobacco plants). And also the calculation process of the number of objects detected by the system. The detection process takes advantage of the different contours between the object and the background. Then the last step is to display the calculation results on the monitor screen.

Table 1. Test results with a distance parameter.

\begin{tabular}{|c|c|c|c|c|}
\hline $\begin{array}{c}\text { Distance } \\
\text { (Meter) }\end{array}$ & $\begin{array}{c}\text { Conventional } \\
\text { Count }\end{array}$ & Detect & Success & Failure \\
\hline 4 & 17 & 20 & $85 \%$ & $15 \%$ \\
\hline 6 & 29 & 34 & $85,29 \%$ & $14,70 \%$ \\
\hline 8 & 39 & 47 & $82,97 \%$ & $17,02 \%$ \\
\hline 13 & 39 & 41 & $95,12 \%$ & $4,87 \%$ \\
\hline 18 & 46 & 42 & $91,30 \%$ & $8,69 \%$ \\
\hline 22 & 49 & 32 & $65,30 \%$ & $34,69 \%$ \\
\hline
\end{tabular}

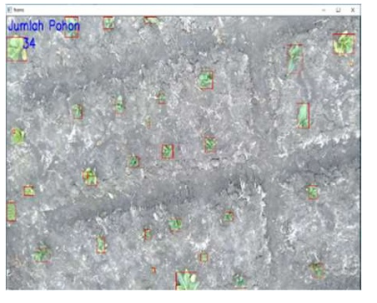

Fig. 9. 4 Meters

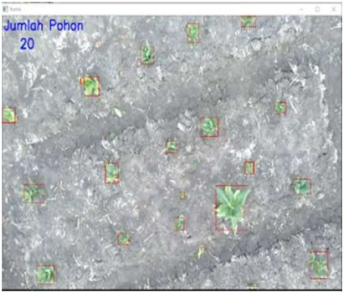

Fig. 10. 6 Meters

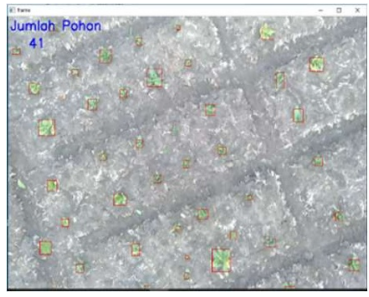

Fig. 11. 8 Meters

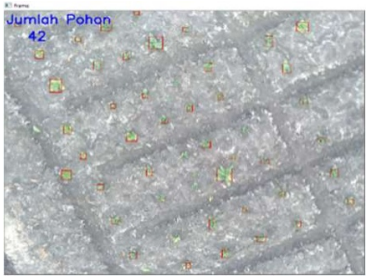

Fig. 13. 18 Meters

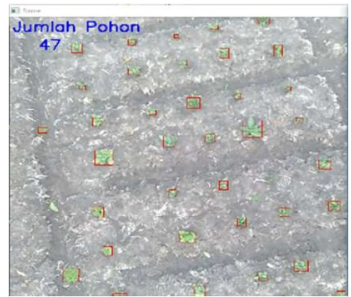

Fig. 12. 13 Meters

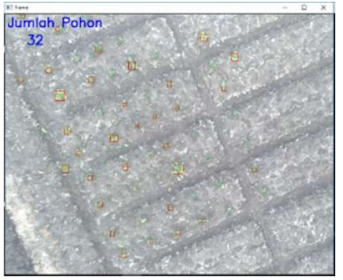

Fig. 14. 22 Meters
From several tests that have been carried out, the test results are obtained as follows: when a distance of 4 meters the success rate is $85 \%$ with an error value of $15 \%$ when a distance of 6 meters the success rate is $85.29 \%$ with an error value of $14.7 \%$ when the distance is 6 meters the success rate is $85.29 \%$ with an error value of $14.7 \%, 8$ meters success rate is $82.97 \%$ with an error value of $17.02 \%$ when a distance of 13 meters the success rate is $95.12 \%$ with an error value of $4.87 \%$ when a distance of 18 meters the success rate is $91.30 \%$ with the error value is $8.69 \%$ when the distance is 22 meters the success rate is $65,30 \%$ with an error value of $34.69 \%$. From the test results, it can be analyzed that the highest success rate is at a distance of 13 meters and the lowest success rate is at a distance of 22 meters. With the test results, many factors affect the value of the detection results. At a distance of 22 meters, the success rate is $65.30 \%$. Judging from the image distance 13 that the color of the plant is getting fainter which affects the RGB rating of the image, so the detection results are less than optimal. While at a distance of 13 meters the success rate is $95.12 \%$. It can be seen from Figure 11 that the color of the plant looks different from the background so that the RGB image matches the RGB input, so the detection results have a small error value.

\subsection{Testing using the time parameter}

The second test is carried out using the time parameter. i.e., in the morning at $05.30-06.30 \mathrm{WIB}$.

Table 2 shows the results of the automatic plant calculation test at $05.30-06.30$ WIB. By getting the results of the average success of the trial of $86.597 \%$. The number of objects detected was 840 trees out of a total of 970 tobacco trees. 
Table 2. Testing at $05.30-06.30 \mathrm{WIB}$.

\begin{tabular}{|c|c|c|c|c|}
\hline Testing & Conventional count & Detected & Not detected & Description \\
\hline 1 & 48 & 42 & 6 & 87,5 \\
\hline 2 & 52 & 46 & 6 & 88,46154 \\
\hline 3 & 47 & 42 & 5 & 89,3617 \\
\hline 4 & 50 & 46 & 4 & 92 \\
\hline 5 & 45 & 40 & 5 & 88,88889 \\
\hline 6 & 51 & 44 & 7 & 86,27451 \\
\hline 7 & 53 & 48 & 5 & 90,56004 \\
\hline 8 & 46 & 40 & 6 & 86,95652 \\
\hline 9 & 44 & 40 & 4 & 90,90909 \\
\hline 10 & 48 & 40 & 8 & 83,33333 \\
\hline 11 & 54 & 47 & 7 & 87,03704 \\
\hline 12 & 52 & 43 & 9 & 82,69231 \\
\hline 13 & 49 & 40 & 9 & 81,63265 \\
\hline 14 & 47 & 40 & 7 & 85,10638 \\
\hline 15 & 45 & 40 & 5 & 88,88889 \\
\hline 16 & 46 & 40 & 6 & 86,95652 \\
\hline 17 & 43 & 37 & 6 & 86,04651 \\
\hline 18 & 49 & 41 & 8 & 83,67347 \\
\hline 19 & 48 & 41 & 7 & 85,41667 \\
\hline 20 & 53 & 43 & 10 & 81,13208 \\
\hline \multicolumn{5}{|r|}{ Rata rata } \\
\hline
\end{tabular}

Conventional count:

$\begin{array}{ll}\text { Object } & =970 \\ \text { Counted object } & =840 \\ \text { Uncounted object } & =\text { object }- \text { counted object } \\ & =970-840 \\ & =130 \text { trees } \\ \text { Error } & =13,402 \% \\ \text { Success } & =86,597 \%\end{array}$

\section{Summary}

Based on the test results obtained from the automatic plant counter system, it can be concluded that:

1. The automatic plant calculation process can run as expected by utilizing several software and hardware requirements. Software requirements needed are: python, OpenCV, droid cam while hardware requirements include: PC, cellphone, drone, Esp module

2. The automatic crop calculation process has a working principle, PC and drone cameras are connected with the same internet ID using the same Wifi, so they can send image data. The image data sent by the drone camera is then processed using the contour detection method, by going through several processes, namely masking, closing, and opening. The calculation result display appears on the PC monitor screen.

3. From the test results, it can be seen the level of accuracy of the automatic plant counter system. From the test results, the results obtained in the first test obtained a success rate of $86,597 \%$ with an error of $13,402 \%$. The results of the second test obtained a success rate of $87.693 \%$ with an error of $12.306 \%$. The results of the third test obtained a success rate of $87,033 \%$ with an error of $12,966 \%$. The results of the fourth test obtained a success rate of $85,431 \%$ with an error of $14.56 \%$. To get accurate results, the things that affect are the light, the distance of the object with the drone camera. Then accurate results can be obtained by knowing the appropriate distance and light.

\section{References}

[1] R. T. Muktianto and H. C. Diartho, "Komoditas Tembakau Besuki Na-Oogst dalam Perspektif Pembangunan Berkelanjutan di Kabupaten Jember," Caraka Tani J. Sustain. Agric., vol. 33, no. 2 , p. 115, (2018), doi: 10.20961/carakatani.v33i2.20598.

[2] Y. Putri and R. Sumiharto, "Purwarupa Sistem Prediksi Luas dan Hasil Panen Padi suatu Wilayah menggunakan Pengolahan Citra Digital dengan Metode Sobel dan Otsu," IJEIS (Indonesian J. Electron. Instrum. Syst., vol. 6, no. 2, p. 187, (2016), doi: 10.22146/ijeis. 15258

[3] D. H. Sulistyawati, "Analisa Citra Parasit Malaria Dalam Ruang Warna Hue Saturation Value ( HSV )," J. Has. Penelit. LPPM Untag Surabaya, vol. 03, no. 01, pp. 63-66, (2018).

[4] I. Uktoro, "Analisis Citra Drone Untuk Monitoring Kesehatan Tanaman Kelapa Sawit," J. Agroteknose, vol. 7, no. 2, pp. 8-15, (2017).

[5] A. P. W. Wibowo and I. Rijayana, "Implementasi Teknologi Smart Drone Dan Citra Udara Untuk Monitoring Pertumbuhan Kelapa Sawit," Semnasteknomedia Online, pp.s 13-18, (2017).

[6] S. Perhitungan, J. Pohon, and M. R. Caeli, "METODE KLASIFIKASI BERBASIS OBJEK ( Studi Kasus: Perkebunan Kelapa Sawit, di Kecamatan Kintap , Tanah Laut )," (2016).

[7] K. Ayuningsih, Y. A. Sari, and P. P. Adikara, "Klasifikasi Citra Makanan Menggunakan HSV Color Moment dan Local Binary Pattern dengan Naïve Bayes ClassifierAyuningsih, Karunia, Yuita Arum Sari, and Putra Pandu Adikara. 2019. "Klasifikasi Citra Makanan Menggunakan HSV Color Moment Dan Local Binary Patt," J. Pengemb. Teknol. Inf. dan Ilmu Komput. Univ. Brawijaya, vol. 3, no. 4, pp. 3166-3173, (2019).

[8] J. F. Fauzi, H. Tolle, and R. K. Dewi, "Implementasi Metode RGB To HSV pada Aplikasi Pengenalan Mata Uang Kertas Berbasis Android untuk Tuna Netra,” J. Pengemb. Teknol. Inf. dan Ilmu Komput., vol. 2, no. 6, pp. 23192325, (2018).

[9] E. Ardhianto, W. Hadikurniawati, and Z. Budiarso, "Implementasi Metode Image Subtracting dan Metode Regionprops untuk Mendeteksi Jumlah Objek Berwarna RGB pada File Video," J. Teknol. Inf. Din., vol. 18, no. 2, pp. 91-100, (2013).

[10] D. Derisma, "Perbandingan Kinerja Metode Deteksi Tepi Pada Pengenalan Objek Menggunakan Open CV," Inform. Mulawarman J. Ilm. Ilmu Komput., vol. 11, no. 2, p. 17, (2016), doi: 10.30872/jim.v11i2.209.

[11] S. Hadi, A. Akmal, and S. Herlina, "Klasifikasi Objek Terdeformasi Berdasarkan Nilai Deviasi Menggunakan Metode Kontinuitas Kontur,' J. Mat. Integr., vol. 10, no. 2, p. 117, (2014), doi: 10.24198/jmi.v10.n2.10254.117-126.

[12] A. Jalil, "Deteksi Gerak Objek Berbasis Pengolahan Citra Menggunakan Metode Binary- 
Image Comparison," Electro Luceat, vol. 6, no. 1, pp. 109-116, (2020), doi: 10.32531/jelekn.v6i1.207.

[13] E. D. Ginting, "Deteksi Tepi Menggunakan Metode Canny Dengan," Http://Repository.Gunadarma.Ac.Id/1013/, (2014).

[14] FAO, Climate-Smart Agriculture - Training Manual for Agricultural Extension Agents in Kenya. (2018).

[15] U. R. Mogili and B. B. V. L. Deepak, "Review on Application of Drone Systems in Precision Agriculture," Procedia Comput. Sci., vol. 133, pp. 502-509, (2018), DOI: 10.1016/j.procs.2018.07.063. 